\title{
FIRST RECORD OF PSENES PELLUCIDUS (PERCIFORMES, ACTINOPTERYGII) IN THE SARDINIAN WATERS (CENTRAL WESTERN MEDITERRANEAN)
}

\author{
M. Cristina FOLLESA, Serenella CABIDDU, Andrea SABATINI, Angelo CAU
}

Department of Animal Biology and Ecology, University of Cagliari, Italy
Follesa M.C., Cabiddu S., Sabatini A., Cau A. 2006. First record of Psenes pellucidus (Perciformes, Actinopterygii) in the Sardinian waters (central western Mediterranean). Acta Ichthyol. Piscat. 36 (1): 77-79.

\begin{abstract}
The first record of Psenes pellucidus Lütken, 1880, (Nomeidae) in Sardinian waters (Central western Mediterranean) is reported. The present finding appears to be an interesting stage of transformation from the juvenile to the more elongate form of an adult.
\end{abstract}

Keywords: fish, zoogeography, thermophilic species, Psenes pellucidus, first record, Sardinia, central western Mediterranean

The bluefin driftfish, Psenes pellucidus Lütken, 1880, is a meso-bathypelagic fish medium size (i.e., up to about $80 \mathrm{~cm}$ of length). The juveniles are commonly found hovering under floating objects, whereas the large adult may be demersal on continental slopes (Robins and Ray 1986, Haedrich 1990). The species has a wide geographical distribution, occurring in tropical and some temperate waters of the Indian-, Pacific-, and Atlantic oceans. In the Mediterranean Sea, although the species has traditionally been considered as rare, several findings have been recorded. The first capture was registered in Algeria (Dieuzeide and Roland 1955, Bauchot 1987) and the species was successively recorded from Morocco (Maurin 1962, 1968), Balearic Islands (Riera et al. 1997), Strait of Messina (Berdar et al. 1995), and Gulf of Lions and Provance (Quignard and Tommasini 2000). From previous data it is clear that the species shows a non-homogenous distribution within the Mediterranean Sea. In this short note, the first record of the bluefin driftfish in Sardinian marine waters is reported.

The specimen of $P$. pellucidus was caught in April 2005 during a commercial bottom trawl hauled at about $600 \mathrm{~m}$ of depth (Toro's Island) (Fig. 1). The fish was frozen on board by fishermen. Once in the laboratory, the specimen was photographed, measured, and weighed (Fig. 2). Taxonomic identification and general nomenclature were mainly based on literature (Haedrich 1973, 1986, 1990). The sex and the gonad maturation stage (Holden and Raitt 1974) were also registered.

The specimen is an interesting example. It is at the stage of transforming from the deeper-bodied juvenile to the more elongate form of an adult, at which time it looses its colour pattern and becomes rather dark.

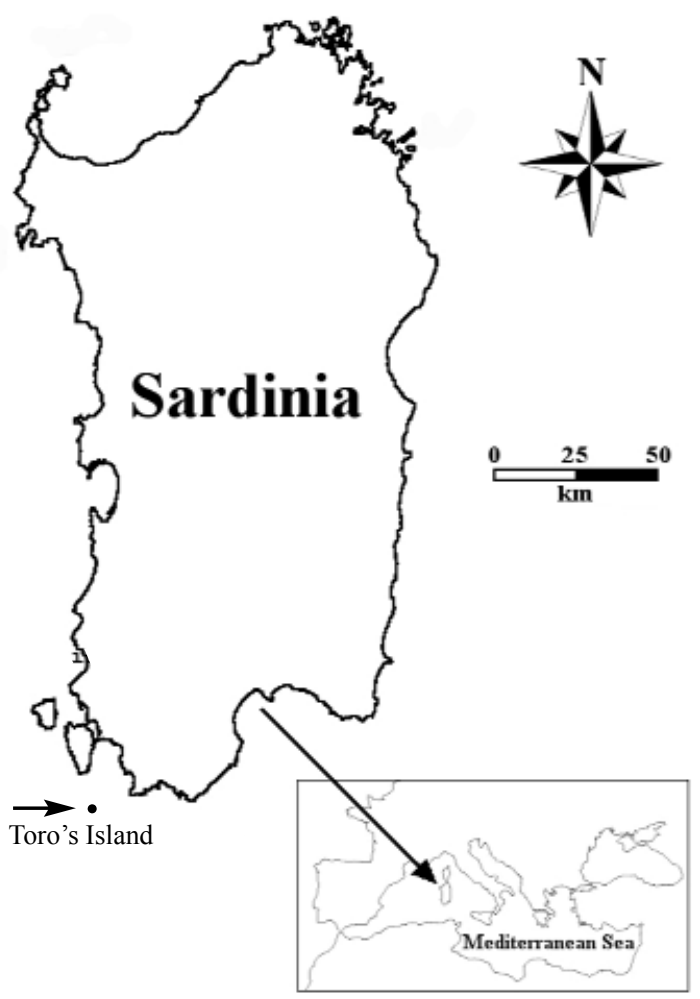

Fig. 1. Location where the presently described Psenes pellucidus was taken 


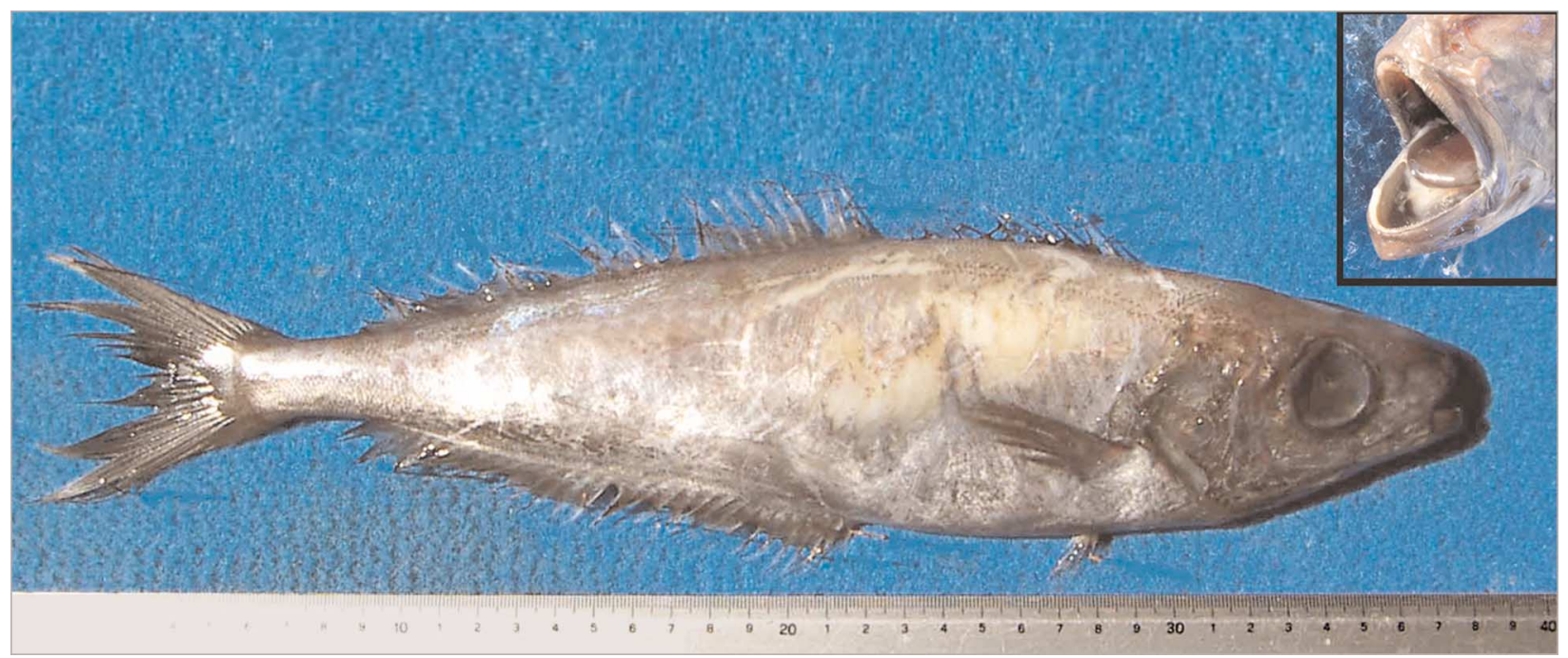

Fig. 2. Psenes pellucidus Lütken, 1880; inset shows the diagnostic teeth in the upper and lower jaw

The most diagnostic macroscopic features were also evident, in particular the teeth in the lower jaw are flattened, close-set, long and blade-like and very different from the smaller recurved and pointed ones in the upper jaw (Haedrich and Horn 1972). The basic morphometric measures (as absolute values and indexes of standard length) were also reported (Table 1). No meristic or mor- phological data are available in the literature for the other Mediterranean specimens. The reproductive period of the species in the Mediterranean Sea is also not known. Our specimen appears a male with immature gonads (stage II). The occurrence of this species in Sardinian waters is a new evidence of the extension in latitude of its geographical distribution. It could be also a sign of ecological changes

Table 1

Morphological and meristic data for the specimen of Psenes pellucidus caught in Sardinian waters

\begin{tabular}{lcc}
\hline Morphometric data & Empirical value & $\begin{array}{c}\text { Relative value } \\
\text { [\% of standard length] }\end{array}$ \\
\hline Total length [mm] & 381.0 & \\
Standard length [mm] & 312.0 & \\
Fork length [mm] & 341.0 & 42.31 \\
Anal length [mm] & 132.0 & 9.01 \\
Predorsal length [mm] & 90.52 & 26.73 \\
Head length [mm] & 83.4 & 5.99 \\
Horizontal eye diameter [mm] & 18.7 & 25.13 \\
Preorbital space [mm] & & 59.94 \\
Body height [mm] & 78.4 & 15.38 \\
Dorsal fin base length [mm] & 187.0 & 40.87 \\
Pectoral fin base length [mm] & 48.0 & 6.60 \\
Anal fin base length [mm] & 127.5 & \\
Ventral fin base length [mm] & 20.6 & \\
Total weight [g] & 268.6 & \\
\hline Meristic data & & \\
\hline Dorsal fin rays & XI+34 \\
Ventral fin rays & 6 & \\
Pectoral fin rays & 18 & \\
Caudal fin rays & 32 & \\
Anal fin rays & II+31 \\
\hline
\end{tabular}


in local sea conditions suggested as a general event in the western Mediterranean by Riera et al. (1997).

\section{ACKNOWLEDGEMENTS}

Many thanks are due to Richard L. Haedrich (Memorial University of Newfoundland, Canada) for his helpful suggestions.

\section{REFERENCES}

Bauchot M.L. 1987. Family Carangidae. Pp. 1009-1030. In: Fischer W., Bianchi G., Scott W.B. (eds.) Fiches FAO d'identification des espèces pour les besoins de la pêche. Mediterranee et Mer Noire (Zone de pêche 37). FAO, Rome.

Berdar A., Capecchi D., Costa F., Giordano D., Mento G., Spalletta, B. 1995. Pesci parassiti e pseudoparassiti dei mari italiani. [Fish parasites and pseudoparasites of Italian seas.] Rivista di parassitologia 12/56: 454-465. [ In Italian.]

Dieuzeide R., Roland J. 1955. Sur un Stromateidae nouveau du genre Cubiceps. Bulletin des travaux publiés par la station d'aquicolture et de pêche de Castiglione (nouvelle serie) 7: 341-368.

Haedrich R.L. 1973. Nomeidae. Pp. 562-563. In: Hureau J.C., Monod Th. (eds.) Check-list of the fishes of the north-eastern Atlantic and the Mediterranean CLOFNAM, UNESCO, Paris.

Haedrich R.L. 1986. Nomeidae. Pp. 1183-1188. In: Whitehead P.J.P., Bauchot M.-L., Hureau J.-C., Nielsen J., Tortonese E. (eds.) Fishes of the North-eastern Atlantic and the Mediterranean. Vol. 3. UNESCO, Paris.

Haedrich R.L. 1990. Nomeidae. Pp. 1014-1018. In: Quero J.C., Hureau J.-C., Karrer C., Post A., Saldanha L. (eds.) Check-list of the fishes of the eastern tropical Atlantic (CLOFETA). Vol. 2. JNICT, Lisbon; SEI, Paris; UNESCO, Paris.
Haedrich R.L., Horn M.H. 1972. A Key to the stromateoid fishes. Woods Hole Ocenographic Institution. Technical Reports No. 75.

Holden M.J., Raitt D.F.S. 1974. Manual of fisheries science. Part 2. Methods of resource investigation and their application. FAO Fisheries Technical Papers No. 115.

Maurin C. 1962. Etude des fonds chalutables de la Méditerranée occidentale (Ecologie et Pêche). Résultats des campagnes des navires océanographiques «Président-ThéodoreTissier» 1957 et 1960 et «Thalassa» 1960 et 1961 . Revue des Travaux de l'Institut des Pêches maritimes 26 (2): 163-218.

Maurin C. 1968. Ecologie ichthyologique des fonds chalutables atlantiques (de la baie ibéro-marocaine à al Mauritanie) et de la Méditerranée occidentale. Revue des Travaux de l'Institut des Pêche maritimes 1: 1-147.

Quignard J.P., Tomasini J.A. 2000. Mediterranean fish biodiversity. Biologia Marina Mediterranea 7 (3): 1-66.

Riera F., Grau A.M., Pastor, E., Pou S. 1997. Faunistical and demographical observation in Balearic ichthyofauna. Meridionalization or subtropicalization phenomena. Pp. 213220. In: Actes du Colloque Scientifique (Okeanos): «La Méditerranée: Variabilités climatiques, environnement et biodiversité». 5-7 abril 1995, Montpellier, France.

Robins C.R., Ray G.C. 1986. A field guide to Atlantic coast fishes of North America. Houghton Mifflin Company, Boston.
Received: 6 March 2006

Accepted: 12 June 2006 